\title{
Implementation Of The Police Role In Doing Control And Law Enforcement Against Police In Area Community Organization Indramayu Associated With Act No. 17 In 2013 Jo. Act No. 162018
}

\author{
Sunardi ${ }^{1}$ and Sri Kusriyah ${ }^{2}$
}

Abstract. In this study the issues to be discussed are: Implementation of the National Police's role in conducting oversight and enforcement of the law against Society. Any barriers faced by the police in doing supervision and enforcement of the law against Social Organization. Police made solutions in overcoming these obstacles above. The methodology used by researchers is the approach empirical juridical, as for sources and types of data in this study are primary data obtained from field studies withway direct communication with the respondent or informant (CJS), And secondary data obtained from the study of literature. Based on the results of research that: the application of the national police role Indramayu in conducting oversight and enforcement of the law against Social Organization that efforts emptive, ie policing effort in order to provide guidance to the public through the development activities of the community that runs from the function Unit Binmas, such as providing information to the public, placement Bhabinkamtibmas in every village one member the Police; Barriers faced is insufficient budget for operations; In the displacement of the secretariat of $\mathrm{CBO}$, $\mathrm{CSO}$ s are rarely reported to the Police Indramayu; Shortage of Human Resources in terms of the establishment of the superintendent; Solutions to overcome these obstaclesthat Bakesbangpol only as a facilitator who records a list of community organizations and in coordination with the central government, while the direct supervision of the CSOs do not have the authority expressly in supervision, coaching, and dissolution of CSOs.

Keywords: Implementation; Monitoring; Enforcement; Community Organizations.

\section{Introduction}

In the course of the development of law in this case the law on civic organizations experienced several changes that are considered government is very necessary and urgent, and their legal vacuum when it is deemed necessary, so that the government in this case the President based on the authority given by the Constitution to issue a regulation Substitute government Act no. 2 in 2017 and has been endorsed by the House of Representatives by Act no. 16 of 2018, so Perpu number 2 in 2017 has rightfully become law.

Circumstances at the time was considered very necessary and urgent and the case their legal void the acts that have not been regulated in the law governing civic organizations, such as when the nationwide wave of protests against Ahok size of demonstrations the up to hundreds of thousands, including their effort which can

\footnotetext{
${ }^{1}$ Student of Masters (S2) of Law Faculty of Law Unissula Semarang and Members of the Police email myongardi@gmail.com

${ }^{2}$ Lecturer of Faculty of Law UNISSULA Semarang
} 
lower state authority through effort treason and leads to deflection ideology of Pancasila ${ }^{3}$, So that the president based on power issued Perpu number 2 in 2017 on community organizations.

In a case that began with a rally formally notify the police resorts Indramayu implemented by community groups on behalf of "the Peasant Union Indramayu" or abbreviated STI with the demands of rejecting the project construction of reservoirs Porridge Gadung in the village of Loyang subdistrict Cikedung Indramayu, led by Br. Rojak, which takes place on Sunday, August 25, $2013^{4}$.

Police Chief Indramayu Superintendent Rev. Bintono, SIK, MH paying particular attention to the situation after the arrest of five of the perpetrators is Br. Rojak Cs, and with reason conduciveness the district of Indramayu against all five suspects were later deposited in a detention center Polda West Java, and the implementation of the hearing held Bandung District Court.

It is appropriate that an unlawful act will have consequences for the laws that have been set, so there is a deterrent effect for offenders over the deeds he has done, and as HA Mukti Arto write that "... justice will be realized when the parties are obliged to have fulfilled what the conscience justice into obligations." ${ }^{5}$

Further in his substance HA Mukti Sunattulah Arto also explain the laws of nature that there are some rules of origin of obligations and responsibilities, namely: first, the strong must protect the weak; second, the parties become a cause shall be liable for any damages other party arising as a result; and the third, who does must be responsible for any consequences thereof ${ }^{6}$.

Returning to the subject of one example of a case that the writer tell the above that the event on behalf of the social organization "Farmers Union Indramayu" which is led by the Secretary General of the STI Br, Rojak, which in turn must be responsibility accountable in the eyes of law, so it does not mean their freedom of assembly and association under the auspices of the civil society organizations can not be reached by law / impunity, but everyone gets the same legal treatment.

Based on the above description of the background, then there are issues to be addressed in this study are: What is the role of the Police in conducting Implementation Monitoring and enforcement of the law against oganisasi Community? Any barriers faced by the police in doing supervision and enforcement of the law against Social Organization? What solution do as well as the Police to tackle these obstacles over?

\section{Research Methods}

In this study used legal research is empirical juridical (legal empirical reseach) ${ }^{7}$ legal research is based on field research or primary data research to understand the symptoms of law mencakut in society associated with the general principles of law,

3 https://news.detik.com/berita/d-3559419/wiranto-perpu-ormas-mendesak-ada-ancaman-terhadapideologi-negara

${ }^{4}$ www.pikiran-rakyat.com

${ }^{5}$ H.A. Mukti Arto Penemuan Hukum Islam Demi Mewujudkan Keadilan Jakarta Pustaka Pelajar (2006) p.26

${ }^{6}$ Ibid.

${ }^{7}$ Ibid. 
rule of law, legislation, ${ }^{8}$ related to the duties and authority of the Police to carry out supervision and enforcement of the law against Social Organization. In this thesis the type of research is descriptive analysis, the research dinaksudkan to humans, objec / other symptoms. ${ }^{9}$

\section{Results And Discussion}

\subsection{Implementation of the National Police's Role In Conducting Oversight And Enforcement Of The Law Against Oganisasi Community}

In maintain security and public order, the existence of civil society organizations must not be separated from how the police can monitor the activity of groups of people should not be held social organization activities that have an impact on the security and public order disturbances, which in turn would result in the violation of the law.

Effort relating to supervision of the civic organization's activities in accordance with the duties and functions of police effort organized as follows:

- Emptive efforts, the efforts of the police in order to provide guidance to communities through community development activities of the Unit Binmas runs from the functions, such as providing information to the public, Bhabinkamtibmas placement in each village one member of the Police;

- Efforts Peventif, namely effort police in order to maintain the security situation and order community to eliminate the convergence of intentions offenders with opportunities / situations that provide opportunities for criminals and preventive activities can be carried out by means of patrol, guard and escort implemented Sabhara Unit.

Apart from that the police have the authority in order to carry out law enforcement against offenses that occurred. In accordance with the Police Regulation No. 23 of 2010 on the Organizational Structure and Work at the level of Police and the Police Sector, that the Police (Police) within its organizational structure divided into 5 groups of elements, namely: 1) The element of leadership that consists of the Chief of Police and Waka Police; 2) Elements of Trustees and Vice Chairman consisting of the Head of Section and Head; 3) Elements of Acting Principal consisting of Head of Unit; 4) Support Elements that the Police Information Technology Section (Sitipol), and; 5) The element of territorial namely Acting Police Chief.

In the Police Regulation No. 23 of 2010 has been explained about the duties and functions of each element of the police station and police station level policing, that is the function of overseeing the handling of oversight activities and activities of the general public, both individuals and groups and agencies. In this case the police functions are as follows:

- Operations Division (Bagops)

Operations Division, led by Head of Ops, a supervisor and a co-leader element under the Chief of Police. Administration in charge of planning and control of police operations, the security community activities and / or government agencies,

\footnotetext{
${ }^{8}$ Soerjono Soekanto dan Sri Mamudji Penelitian Hukum Normatif suatu Tujuan Singkat (Jakarta : Radja Grafindo Persada 2001) p.11

${ }^{9}$ Bambang Sunggono Metodologi Penelitian Hukum (Jakarta : Rajawali Press 1997) p.36
} 
provide information and documentation activities and mengedalikan Security Police headquarters.

- IntelkamUnit

Intelkam unit led by Adj Intelkam, is implementing elements of the basic tasks under the Chief of Police. In charge of organizing and building the field of security intelligence functions, services related to the general hustle and publishing licenses SKCK, receive notifications of community activities or political activities, as well as make recommendations on the application for permit holders of firearms and the use of explosives.

Unit functions Intelkam, held:

- Development of intelligence activities in the field of safety, such as coding and product intelligence in the police station;

- Operational activities of security intelligence for the implementation of early detection (early detection) and warning (early warning), through information network development personnel carrier Intelligence function;

- The collection, storage, and updating of the biodata formal or informal leaders of social organizations, society, politics, and local governments;

- Documenting and analyzing the development of the strategic environment as well as the formulation of intelligence products to support the activities of the Police;

- Preparation of security intelligence forecasts and presents the results of analysis of any developments that need to get leadership's attention;

- Issuing a permit for the hustle and community events among others in the form of a party (festivals, fairs, concerts), parades, fairs, exhibitions, fairs and performances / games or dexterity;

- Publishing STTP for community activities, among others, in the form of meetings, siding, conferences, congresses, seminars, gatherings, appointment of cadres, panel discussions, interactive dialogue, outward bound, and political activities, and;

- SKCK services as well as on the use of firearms and explosives.

- Criminal Investigation Unit (Satreskrim)

Criminal Investigation Unit led by Invisible Criminal, is implementing elements of the basic tasks under the Chief of Police. Melaksnakan duty investigation, investigation and supervision of criminal investigations, including the identification and forensic laboratory field as well as guidance, coordination and supervision of investigators.

Function of the Criminal Investigation Unit, held:

- Technical Pembianaan to administrative inquiries and investigations, as well as the identification and forensic laboratory field;

- Services and special protection to adolescents, children, and women both as perpetrators and victims in accordance with the provisions of the legislation;

- The identification for the purpose of investigation and public services;

- Pengalisisan case along with management, and assess the effectiveness of the implementation of tasks Satreskrim; 
- Pelaksnaan supervision of criminal investigations conducted by investigators at the police unit and Satreskrim Criminal Police;

- Guidance, coordination and supervision of investigators both operational and administrative areas of the investigation in accordance with the provisions of the legislation;

- Inquiry and investigation of criminal offenses generally and specifically, among other economic crimes, corruption, and a specific criminal offense in the legal area police station.

Polres Indramayu in carrying out the primary task and function in providing protection, shelter and service to the community and ensures law enforcement would have to uphold Human Rights as mandated by the Constitution of the Republic of Indonesia in 1945, as well as in relation to the activities of civil society organizations, for example in terms of the activities of civil society organizations in the delivery of public opinion or a demonstration of the existence of things or issues that are considered less appropriate in society.

\subsection{Any Obstacles Encountered In Conducting Oversight Police And Law Enforcement Against Social Organization}

Acts of violence committed organizations often occur and are feared to divide the unity that has existed in Indonesia. Meanwhile, the Ministry of Internal Affairs tasked with monitoring the presence of the mass organizations find it difficult to supervise and conduct training, especially there are many organizations that have not been officially registered in the Ministry of Internal Affairs, so Kemendagri difficult to sanction the mass organizations which violate the peace and security in the absence of the rule execution of Act no.17 Of 2013. Therefore, in line with the issuance of Act no.17 Of 2013 on Civil Society Organizations is necessary to study the importance of the supervision of CSOs as an implementation of Article 53 of Act no. 17 Of 2013.

The results of field research by interviewing the Indramayu Police, Adj Intelkam AKP. Sudiro, $\mathrm{SH}^{10}{ }^{10}$, The constraints faced by the police station in Indramayu Organizations such as surveillance following:

- Operational budget is not sufficient;

- In the displacement of the secretariat of $\mathrm{CBOs}, \mathrm{CSO}$ are rarely reported to the Police Indramayu;

- Shortage of Human Resources in terms of the establishment of the superintendent;

- Does not have jurisdiction in the case directly to the dissolution of an organization whose activities conflict with Perppu CSOs;

- During the Mass Organizations Law applies, Indramayu Police very weak position to participate supervise and disperse CSOs as yet in the form of an integrated team as listed in Article 13 of Regulation CSOs. While the new CSOs Regulation was published in July 2017 so that implementation is not maximized.

Other constraints faced by the field during the Indramayu Police are in terms of supervision bodied Organizations Law directly submitted to the Ministry of Justice, thus providing an opportunity for CSOs established domicile obscure existence. Due to the establishment of the entity Organizations Law was established by Deed without

\footnotetext{
${ }^{10}$ Interview with the AKP. Sudiro SH on July 102018 at 8:45 pm
} 
checking the location of the secretariat by the Notary. It was very different to that CSOs are not the establishment of a legal entity which is monitored by the authorities (Police Indramayu), because before issued an SKT, the secretariat checks through Bakesbanpol CBOs will be registered, so it is easier to do logging.

These conditions are an obstacle for the police station in Indramayu record and oversee CSOs registered as CSOs incorporated under the Law, whereas in case of any problems the community organizations that violate the statutory provisions within the community, the Central Government waiting for the report in advance of the Police Indramayu to be able to follow up on these issues, both in terms of the application of sanctions against violating $\mathrm{CBO}$ s and dissolution, so the Indramayu Police had no authority direct execution, merely provide reports and inputs to the Central Government.

\subsection{Police Made Solutions To Overcome These Obstacles Above}

It is undeniable that the contribution of CSOs in governance and development is very big. It has been proved since the struggle for independence to the present. But it also can not be denied that there are most CSOs are in a range of activities would lead to unrest in society. The existence of such a mass organization that has created the conditions adage, rotten apples damaged because of milk. ${ }^{11}$

Results of interviews with Indramayu Police, Adj Intelkam AKP. Sudiro, $\mathrm{SH}^{12}$ at the police station, that the measures under scrutiny carried out by the Police CSOs Indramayu field as it appears on the Indonesian Government Regulation No. 58 of 2016, that Bakesbangpol only as a facilitator who records a list of community organizations and in coordination with the central government, while the direct supervision of the CSOs do not have the authority expressly in supervision, coaching, and dissolution of CSOs.

Birth of CSOs memeperketat Perpu Technical Supervision is to form a unified team as listed in Article 13,14,15 and 16 Pemendagri CSOs specifically regulating the environment Kemendagri Oversight Organizations and Local Government (LG), while the integrated team comprised of elements as following:

- Ministry of Justice and Human Rights;

- Ministry of Social Affairs,

- Ministry of Foreign Affairs;

- Police Headquarters of the Republic of Indonesia;

- Attorney General, CBOs field Indonesian National Armed Forces Headquarters; and

- State Intelligence Agency

Another step in conducting surveillance Police Indramayu able to search data on CSOs registered in West Java, and always coordinated with the National Intelligence Agency (BIN), Police (Police), and the Regional Military Command (military command), to provide information and report to the Central Government in the event of their CSOs are problematic in a society such as the conflict between CSOs, $\mathrm{CBO}$ s who conduct

\footnotetext{
${ }^{11}$ https://media.neliti.com/media/publications/52270-ID-urgensi-pengawasan-organisasikemasyarak.pdf accessed on 03-08-2018 at 14:05 am.

${ }^{12}$ Interview with the AKP. Sudiro SH on July 102018 10:00 pm
} 
activities contrary to public order, or which is contrary to the ideology of Pancasila or community organizations whose activities were prohibited by the legislation.

\section{Closing}

\section{Conclution}

Based on the results of research and discussion it can be concluded as follows:

- Polres Indramayu in carrying out the primary task and function in providing protection, shelter and service to the community and ensures law enforcement would have to uphold Human Rights as mandated by the Constitution of the Republic of Indonesia in 1945, as well as in relation to the activities of civil society organizations, for example in terms of the activities of civil society organizations in the delivery of public opinion or a demonstration of the existence of things or issues that are considered less appropriate in society.

- In the case of CSOs bodied supervision law directly submitted to the Ministry of Justice, thus providing an opportunity for CSOs established domicile obscure existence. Due to the establishment of the entity Organizations Law was established by Deed without checking the location of the secretariat by the Notary. It was very different to that CSOs are not the establishment of a legal entity which is monitored by the authorities (Police Indramayu), because before issued an SKT, the secretariat checks Bakesbanpol CBOs will be registered, so it is easier to do logging.

- CSOs in monitoring conducted by the Police Indramayu field as it appears on the Indonesian Government Regulation No. 58 of 2016, that Bakesbangpol just as facilitators who record list $\mathrm{CBOs}$ and coordinate with the central government, while the direct supervision of the CSOs do not have the authority expressly in supervision, coaching, and dissolution of CSOs.

\subsection{Suggestion}

- In providing services to the community in the delivery of these aspirations Indramayu Police need to take steps in anticipation of that aspiration and its activities can be run safely and orderly.

- Police Indramayu in terms of records and oversee CSOs registered as CSOs incorporated under the Law, whereas in case of any problems the community organizations that violate the statutory provisions within the community, the Central Government waiting for the report in advance of the Police Indramayu to be able to follow up on these issues, either in terms of the application of sanctions against violating $\mathrm{CBO}$ s and dissolution, so the Indramayu Police had no authority direct execution, merely provide reports and inputs to the Central Government.

\section{Bibliography}

[1] Ahmad Fikri Hadin, 2013, Eksistensi Badan Pengawasan Keuangan dan Pembangunan di Era Otonomi Daerah, Yogyakarta, Genta Press.

[2] Bambang Sunggono, Metodologi Penelitian Hukum, (Jakarta : Rajawali Press, 1997). 
[3] Budiono Kusumohamidjojo, dilema antara hukum dan kekuasaan, Jakarta, Yrama Widya, (2016).

[4] Budiono Kusumohamidjojo, terori hukum dilemma antara hukum dan kekuasaan, Yrama Widya, Jakarta, 2016.

[5] Bambang Sunggono, Metodologi Penelitian Hukum, (Jakarta : Rajawali Press, 1997).

[6] H.A. Mukti Arto, Penemuan hukum islam demi mewujudkan keadilan, Jakarta, Pustaka Pelajar, (2006)

[7] Soerjono Soekanto dan Sri Mamudji, Penelitian Hukum Normatif suatu Tujuan Singkat, (Jakarta : Radja Grafindo Persada, 2001)

[8] https://media.neliti.com/media/publications/52270-ID-urgensi-pengawasanorganisasikemasyarak.pdf, accessed on 03-08-2018, at 14:05 Wib.

[9] https://news.detik.com/berita/d-3559419/wiranto-perpu-ormas-mendesak-adaancaman-terhadap-ideologi-negara

[10] www.pikiran-rakyat.com

[11] Perppu No. 2 of 2017 on the Amendment of Act No. 17 of 2013 on Civil Society Organizations,

[12] Interview with the AKP. Sudiro, SH, on July 10, 2018, 10:00 pm

[13] www.pikiran-rakyat.com 